\title{
ESTETIKA PERSEPSI SEBAGAI KONSEP PENGEMBANGAN TARI ISLAMI DI PERGURUAN TINGGI ISLAM
}

\author{
Heni Siswantari ${ }^{1}$, Fery Setyaningrum ${ }^{2}$ \\ 1,2Universitas Ahmad Dahlan \\ 1,2Jalan Ki Ageng Pemanahan No. 19 Sorosutan Umbulharjo Yogyakarta \\ Email: heni.siswantari@pgsd.uad.ac.id ${ }^{1}$, fery.setyaningrum@pgsd.uad.ac.id ${ }^{2}$
}

\begin{abstract}
Abstrak:
Penelitian ini bertujuan untuk menganalisis dan mendeskripsikan bentuk estetika persepsi pendidikan seni tari sebagai konsep dalam pengembangan seni tari perguruan tinggi Islam di Indonesia. Metode penelitian yang digunakan adalah kualitatif dengan teknik pengambilan data melalui observasi, wawancara, dan dokumentasi. Akurasi data dilakukan dengan teknik triangulasi teknik dan sumber, selanjutnya dianalisis dengan model analisis data Milles dan Huberman. Hasil penelitian menunjukkan bahwa konsep estetika persepsi seni tari muncul untuk menjembatani berbagai macam penafsiran tentang tari Islami. Estetika persepsi seni tari dalam pendidikan tinggi Islam merupakan hasil dari pertemuan antara Islam, seni tari dan pendidikan. Pendidikan sebagai lembaga penerjemah ilmu pengetahuan mengakomodasi kebutuhan estetika dalam seni dan etika dalam norma agama menjadi bagian dari dasar pembentukan tari Islami. Diharapkan rumusan estetika persepsi ini dapat digunakan sebagai acuan dalam pengembangan pendidikan seni tari di perguruan tinggi Islam di Indonesia.
\end{abstract}

\begin{abstract}
:
This study aims to analyze and describe the aesthetic form of dance education perception as a concept in the development of dance Islamic tertiary institutions in Indonesia. The research method used was qualitative with observation, interview, and documentation data collection techniques. Data accuracy finished by triangulation techniques and source techniques, then analyzed with the miles and Huberman data analysis models. The results showed that the concept of aesthetic perception of dance emerged in order to bridge various interpretations of Islamic dance. The aesthetic perception of dance in Islamic higher education is the result of a meeting between Islam, dance, and education. Education as an institution translating knowledge accommodates the aesthetic needs in art and ethics in religious norms to be part of the basis for the formation of Islamic dance. Hopefully, this aesthetic perception formulation can use as a reference in the development of dance education in Islamic tertiary institutions in Indonesia.
\end{abstract}

Kata kunci:

Estetika Persepsi, Tari Islami, Perguruan Tinggi Islam

How to Cite: Siswantari, H., \& Setyaningrum, F. (2019). Estetika Persepsi sebagai Konsep Pengembangan Tari Islami di Perguruan Tinggi Islam. Lentera Pendidikan : Jurnal Ilmu Tarbiyah dan Keguruan, 22(2), 243-253. 


\section{PENDAHULUAN}

Seni memiliki unsur estetika yang menjadi ciri khusus, seperti pada seni tari di perguruan tinggi Islam yang mengutamakan norma (etika) dan unsur estetika agar kedua unsur tersebut menjadi seimbang. Hal ini sesuai pendapat Yusuf dalam Opsantini (2014: 54), yaitu:

"Mengenai keterkaitan antara agama dan kesenian, terdapat dua pandangan yaitu agama merupakan bagian dari kesenian dan kesenian merupakan bagian dari agama. Seni mengekspresikan keindahan Islam dan media dalam menyebarluaskan Islam, sedangkan Islam sebagai pengontrol perkembangan seni agar tercipta karya seni yang bermanfaat, bermutu dan mengandung nilainilai agama."

Islam merupakan agama mayoritas yang cukup memberikan pengaruh terhadap budaya dan seni (Sutrisno, 2011:15). Islam dan seni tumbuh secara berdampingan dengan seni sebagai sebuah budaya dan Islam sebagai pengontrolnya. Seperti seni tari Seudati dari Aceh yang mencerminkan pengaruh Islam dalam kehidupan seni budaya masyarakat Aceh sehingga menjadi media masyarakat Aceh dalam berdakwah menyampaikan nilai-nilai Islam (Mauidhah, 2017:30). Seni dapat menjadi sebuah amalan dan cara untuk mendekatkan diri kepada sang pencipta. Sebagai contohnya Ada beberapa petunjuk Al Qur'an tentang kesenian, antara lain :

1. Islam adalah agama fitrah, agama yang sesuai dengan fitrah manusia (Q.S. 30: 30). Kesenian bagi manusia adalah fitrahnya. Tetapi, bahan yang dimasukan ke dalam saluran itu dapat saja haram hukumnya kalau cara, pelaksanaan, dan tindakannya menyimpang atau bertentangan dengan ketetapan Allah dan Rasulnya (Asriati, 2012:146). Kesanggupan berseni pulalah yang membedakan manusia dari makhluk Tuhan lainnya.

2. Allah itu mempunyai sifat-sifat yang baik (Q.S. 7 : 180), seperti Jamal, (Maha Indah), Jalal (Maha Agung) dan Kamal (Maha Sempurna), manusia mengemban misi sebagai wakil Tuhan, yang harus merealisasikan sifat-sifat Tuhan, sebatas kemampuannya. Dalam hal ini, manusia dapat menerapkan nilai kesenian.

Dari penjelasan di atas maka dapat diambil kesimpulan bahwa kesenian menurut Islam bersifat netral. Seni dapat menciptakan sebuah kebaikan sebagai amal shalih kita kepada sang pencipta, tetapi juga bisa membawa kita ke dalam keburukan apabila kita tidak dapat menggunakan seni dengan sebaik-baiknya. Islam memandang seni sebagai sebuah ibadah yang apabila dilakukan sesuai dengan etika atau norma yang ada dalam Islam.

Pembahasan terkait seni dalam kacamata Islam menjadi isu yang menarik karena seringkali dipandang sebagai hal yang tabu dan dianggap tidak sesuai dengan prinsipprinsip Islami. Akan tetapi, dari berbagai pendapat yang menyatakan bahwa seni tidak berkaitan dengan aqidah Islam, muncul pula berbagai pendapat yang menganggap seni sebagai wujud pengejawantahan ke-Esaan Tuhan. Seperti yang disampaikan Quraish sihab yaitu: 
"Kesenian Islam tidak harus berbicara tentang Islam, ia tidak harus berupa nasihat langsung, atau anjuran berbuat kebajikan, bukan juga abstrak tentang akidah. Seni yang Islami adalah seni yang dapat menggambarkan wujud ini, dengan "bahasa" yang indah serta sesuai dengan cetusan fitrah. Seni Islam adalah ekspresi tentang keindahan wujud dari sisi pandangan Islam tentang Islam, hidup dan manusia yang mengantar menuju pertemuan sempurna antara kebenaran dan keindahan" (Shihab dalam Rizali (2012: 3).

Bagi Sihab seni bukan hanya soal bentuk secara tekstual saja, namun lebih pada semangat atau nilai yang ada pada suatu bentuk karya seni. Salah satunya, tari zapin yang dipertunjukkan hanya pada perayaan acara-acara Hari Besar Agama Islam seperti Tahun Baru Hijriyah, Maulid Nabi Muhammad SAW, dan lainnya (Nurdin, 2016: 174). Dengan demikian, seni menjadi sarana untuk menunjukkan kecintaan hamba-Nya melalui suatu keindahan yang tidak bertentangan dengan cetusan fitrah yang diberikan Tuhan. Dengan demikian, pantas saja bila pendidikan seni menjadi salah satu materi wajib dalam kurikulum pendidikan di perguruan tinggi Islam. Pendidikan seni adalah upaya pendidikan dengan menggunakan seni sebagai medianya dan menjadi bagian penting dalam sistem pendidikan secara menyeluruh dan merupakan unsur strategis dan fungsional bagi upaya pemuliaan manusia (Rohidi, 2016). Sedangkan pemahaman tentang tari menurut Rusliana (1999), yaitu hasil daya kreasi seorang koreografer yang telah diungkapkan oleh penari. Ditegaskan lagi oleh Caturwati (1998) bahwa tari kreasi adalah tarian yang berasal dari hasil karya individu yang memiliki kebebasan dalam pengungkapan, dan tidak berpijak pada aturanaturan tradisi atau standar yang sudah ada, sehingga pendidikan seni tari yang dimaknai dalam penelitian ini adalah merupakan upaya pemuliaan manusia dalam bidang seni tari yang ada dan dikembangkan di institusi atau perguruan tinggi. Perkembangan seni tari tersebut hendaknya menjadi sebuah perubahan kemajuan ke arah yang lebih baik (Aprilina, 2014:4). Kajian selanjutnya adalah mengkaji konsep tari yang sesuai dengan kaidah Islam yang dapat dikembangkan pada perguruan tinggi Islam. Hal ini penting untuk dipahami agar tidak terjadi perbedaan persepsi yang dapat memunculkan tari yang Islami dan kurang Islami yang ada di perguruan tinggi Islam di Indonesia.

Studi pendahuluan penelitian ini dilakukan di tiga perguruan tinggi Islam di Yogyakarta yaitu UAD, UIN dan UII. Penulis memiliki asumsi bahwa semakin merebaknya perguruan tinggi Islam di Yogyakarta, maka memunculkan perspektif baru dalam memandang seni sebagai bagian dalam ilmu pengetahuan. Dengan demikian, maka tidak menutup kemungkinan berkembangnya paradigma tari Islami yang ada di perguruan tinggi Islam lain yang ada di Indonesia. Paradoksial antara Islam dan seni tari muncul seiring perkembangan bentuk karya seni pada perguruan tinggi Islami baik sesuai dengan visi misinya masing-masing ataupun tidak. Fakta di lapangan menunjukkan bahwa aktivitas seni tari pada khususnya, menjadi salah satu kegiatan rutin yang dijalankan atau diikuti oleh mahasiswa di masing-masing perguruan tinggi tersebut. 
Membahas tentang multikultural dan kaitannya dengan pendidikan seni tari tercermin dalam repertoar tari yang dikembangkan. Sebagai contoh adalah di UII dan UIN, karya tari yang sering ditampilkan dan dikembangkan adalah tari yang berasal dari Aceh dan Sumatera yaitu Melayu. Dua bentuk tari ini dianggap paling sesuai dengan kaidah-kaidah Islam. Adapun pengembangan bentuk tari lain hanya tari-tari Jawa yang mereka sebut sebagai tari kreasi. Berbeda halnya di UAD yang seringkali menampilkan repertoar tari nusantara lain juga dikembangkan dengan melakukan berbagai perubahan koreografi. Selain pola imitatif repertoar tari nusantara, aktivitas seni tari di perguruan tinggi Islam juga merambah pada penciptaan karya tari walaupun dalam bentuk yang sederhana.

Sajian karya tari yang ditampilkan berbeda pada karya tari yang berkembang di perguruan tinggi seni atau non seni yang tidak berbasis Islami. Perbedaan tersebut dapat kita lihat dalam beberapa elemen dasar komposisi tari seperti gerak, tema, iringan, tata busana dan tata rias. Dalam segi gerak, memperhatikan etika kesopanan yang tidak menonjolkan bagian tubuh yang sensitif. Gerak tersebut dimaksudkan untuk tidak menggugah nafsu para penonton yang menyaksikannya. Tema tari juga dekat dengan falsafah kehidupan yang tidak mengandung unsur pornografi. Iringan juga seringkali menggunakan musik-musik Islami baik secara instrumental ataupun lyrical. Tata rias dan busana juga sangat berbeda yang selalu identik dengan hijab dan kostum yang tidak menonjolkan lekuk tubuh.

Adaptasi-adaptasi tersebut untuk menunjukkan etika keIslaman dalam pendidikan seni tari di perguruan tinggi Islam. Akan tetapi, bagaimana dengan sisi estetika sebuah karya seni tari yang telah melekat pada unsur pendukung tari itu sendiri. Konsep estetika sendiri dipaparkan oleh Seorang estetikawan kuno dari India yang bernama Bharata Muni menekankan konsep rasa dalam melihat estetika. Ia membahas tentang Natya Shastra (natya, teater, shastra, disiplin) yang menjelaskan bahwa dalam estetika Natya Shastra, yang dimaksud rasa adalah pengalaman estetis pemirsa dalam mempersepsi sebuah karya seni, utamanya seni pertunjukan (Suryajaya, 2016: 247-248).

Etika dan estetika sama-sama pada wilayah aksiologi dan sama-sama mengenai nilai, sama-sama berkaitan dengan manusia baik dengan manusia lain, lingkungan ataupun makhluk lain. Etika dan estetika merupakan hal yang satu dan sama (Anjani, 2015: 4). Etika dan estetika juga sama berada di wilayah yang tak dapat dikatakan, keduanya melibatkan sikap kontemplatif yang mana seseorang memandang dunia sebagai satu kesatuan dan karya seni sebagai ekspresi dari jiwa dan karakter melalui tari (Wittgenstein, 2007). Pendidikan tari yang ada di perguruan tinggi Islam sudah mulai memperhatikan moral yang digunakan agar tidak melanggar ketentuan yang ada dalam Islam. Perkembangan tari pun mulai merebak baik di lingkungan pendidikan tinggi Islam di Indonesia. Oleh karena itu, penting kiranya penelitian ini dilakukan untuk dapat merumuskan konsep Islam dan estetika persepsi yang dapat di gunakan dalam mengembangkan karya seni tari di perguruan tinggi Islam di Indonesia. 


\section{METODE PENELITIAN}

Penelitian ini merupakan penelitian deskriptif dengan pendekatan kualitatif. Subjek dalam penelitian ini adalah kelompok tari mahasiswa di Universitas Ahmad Dahlan (UAD), Universitas Islam Negeri (UIN) Yogyakarta dan Universitas Islam Indonesia (UII) Yogyakarta. Objek penelitian adalah estetika persepsi pendidikan seni tari di perguruan tinggi Islam. Metode pengumpulan data menggunakan teknik observasi, wawancara dan studi dokumentasi. Observasi dilakukan dengan melihat secara langsung perkembangan dan adaptasi tari di 3 perguruan tinggi Islam. Wawancara dilakukan dengan pengampuh kebijakan wakil rektor bidang kemahasiswaan dan ketua dan anggota UKM tari di masing-masing perguruan tinggi. Dokumentasi didapatkan dari salinan dokumen/ arsip berupa foto kegiatan dan AD/ART UKM tari pada tiga perguruan tinggi Islam. Crossceck data dilakukan dengan teknik triangulasi teknik dan sumber. Data yang didapatkan selanjutnya dianalisis dengan model analisis Milles (1992) yaitu reduksi data dengan memilih data yang sesuai dengan kebutuhan penelitian. Kedua yaitu: penyajian data yang disusun setelah mewati proses interpretasi, pemaknaan baik secara emik maupun etik (pandangan mahasiswa dan dosen seni tari di UAD, UIN, dan UII) atau etik (pendangan penulis) terkait estetika karya tari Islami. Ketiga yaitu: proses penarikan kesimpulan yaitu hasil selama proses pelaksanaan penelitian, yakni pengungkapkan keseluruhan persepsi para mahasiswa dan dosen di UAD, UIN, dan UII terkait estetika tari Islami di kampus masing-masing.

\section{HASIL PENELITIAN DAN PEMBAHASAN}

Seni dalam ranah pendidikan menjadi salah satu fokus utama dan selalu dikembangkan dalam sebuah lembaga pendidikan. Salah satu di antaranya, yaitu pendidikan seni tari di lingkungan perguruan tinggi Islam di Indonesia. Pendidikan seni tari di perguruan tinggi merupakan proses transfer pengetahuan terkait seni tari yang termasuk dalam kurikulum pendidikan, baik masuk dalam pembelajaran wajib ataupun kegiatan mahasiswa di luar pembelajaran. Para mahasiswa yang telah memasuki perguruan tinggi memiliki latar belakang dan asal yang berbeda dari seluruh nusantara. Sehingga, pendidikan seni tari yang dijalankan mengarah pada pendidikan multikultural sebagai suatu pendekatan praktik seni dan budaya. Wiley \& Son (2010: 397) mengatakan bahwa:

"Multicultural education assumes a comprehensive school reform effort rather than superficial additions to the curriculum or one-shot treatments about diversity, such as workshop for teacher or assembly program for students"

"Pendidikan multikultural mengasumsikan upaya reformasi sekolah yang komprehensif daripada penambahan yang lebih dangkal terhadap kurikulum atau satu tembakan perlakuan tentang keragaman, seperti lokakarya untuk guru atau program untuk siswa" 
Dengan pemahaman tersebut, maka pendidikan seni tari menjadi salah satu jalan untuk memberikan treatment pada mahasiswa terkait keberagaman yang juga merupakan ciri khas bangsa Indonesia. Perguruan tinggi sebagai instansi di bawah pengawasan pemerintah wajib memberikan pemahaman terkait pendidikan multikultural yang salah satunya melalui pendidikan seni tari. Menarik tentunya ketika keberagaman ini dihadapkan pada perguruan tinggi Islam yang menjunjung tinggi visi misi Islami dalam proses pendidikan. Berbagai bentuk adaptasi dilakukan hingga proses pendidikan seni tari dapat berjalan sesuai dengan prinsip perguruan tinggi Islam.

Berkembangnya pendidikan seni pada lingkup perguruan tinggi Islam menampilkan proses adaptasi pendidikan seni tari dengan mempertimbangkan kemaslahatan umat Islam. Oleh karena itu, perlu adanya sebuah konsep yag dapat dijadikan acuan dalam pengembangan seni tari di perguruan tinggi Islam. Konsep tersebut dapat dirumuskan dengan mempertemukan unsur utama pendidikan seni tari di perguruan tinggi Islam yaitu Islam, seni tari dan pendidikan. Adapun estetika yang muncul dari keterpautan antar masing-masing unsur dapat digambarkan dalam prototype di bawah ini:

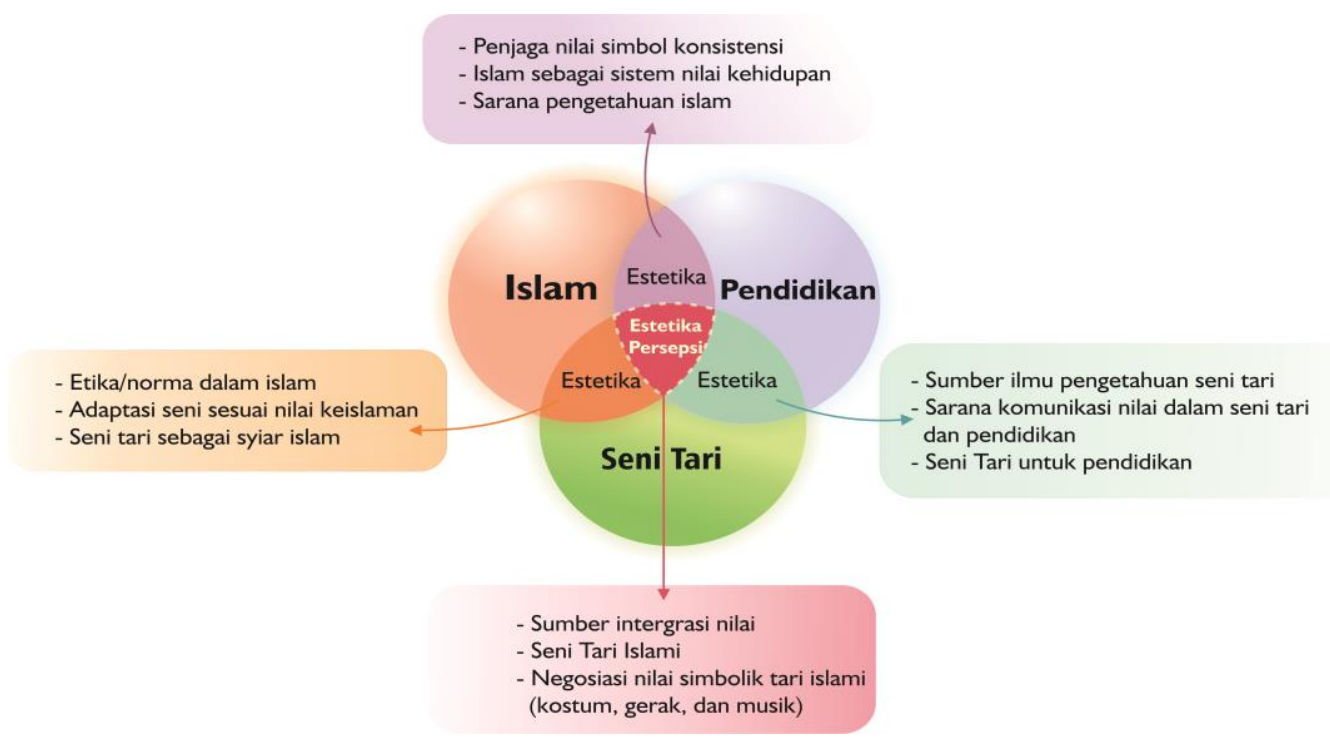

Gambar 1. Prototype Estetika Persepsi Pendidikan Seni Tari Islami

Pada gambar 1 menunjukkan bahwa estetika terbentuk ketika dua hal beririsan satu sama lain. Pada saat Islam bertemu dengan seni tari maka estetika yang muncul akan cenderung dominan pada konsep Islam, sementara seni menjadi bagian di dalamnya. Sebuah penelitian Saeed (2011: 229) tentang seni Islami menyatakan bahwa:

"Muslim artists tried (and still try) to create every art-form by invoking in them the Power and Blessing of the Supreme Reality. It is His gifted creative energy that man can create and appreciate a number of art-forms. While creating "beauty" in his product the artist or architect always thinks of Allah (God) as the Supreme Beauty (Jamal) and He is Present (Hadir) everywhere" 
"Para seniman muslim mencoba (dan masih mencoba) untuk menciptakan setiap bentuk seni dengan memohon kepada mereka kekuatan dan berkah dari realitas tertinggi. Hal ini adalah energi kreatif-Nya yang luar biasa bahwa manusia dapat menciptakan dan menghargai sejumlah bentuk seni. Sementara menciptakan "keindahan" dalam produknya, seniman atau arsitek selalu berpikir tentang Allah (Tuhan) sebagai keindahan tertinggi (Jamal) dan Dia hadir (Hadir) di mana-mana"

Lebih jauh dipaparkan oleh Quraish Shihab bahwa seni Islam menyatakan bahwa suatu seni menjadi Islami, jika hasil seni itu mengungkapkan pandangan hidup kaum Muslimin, yaitu konsep tauhid, sedangkan seniman yang membuat objek seninya tidak mesti seorang Muslim (Shihab dalam Rizali, 2012). Pendapat-pendapat tersebut memungkinkan munculnya berbagai bentuk adaptasi seni tari yang mengacu pada konsep Islam. Pada akhirnya tari yang berkembang berfungsi sebagai wahana untuk syiar Islam bagi masyarakatnya. Meskipun bersandingan, namun pengaruh norma dalam Islam menjadi perhatian khusus ketika tari membawa identitas keIslaman. Sebagai contoh adalah tari sufi yang banyak diketahui oleh masyarakat sebagai tari Islami yang menggambarkan ketaatan kita kepada Allah SWT. Pencipta tari sufi yaitu Jalaludin Rumi adalah seorang filsuf Islam, sehingga karya tari yang diciptakan bukan mengacu pada estetika bentuk tari, namun lebih pada estetika Islam yang digambarkan melalui tari. Sebuah penelitian yang dilakukan oleh Aminah Nur Nasution juga menerangkan bahwa di Yogyakarta terdapat tari Badui yang menjadi media dakwah Islam dengan syair-syair yang dinyanyikan adalah puji-pujian terhadap Allah SWT (Nasution, 2017).

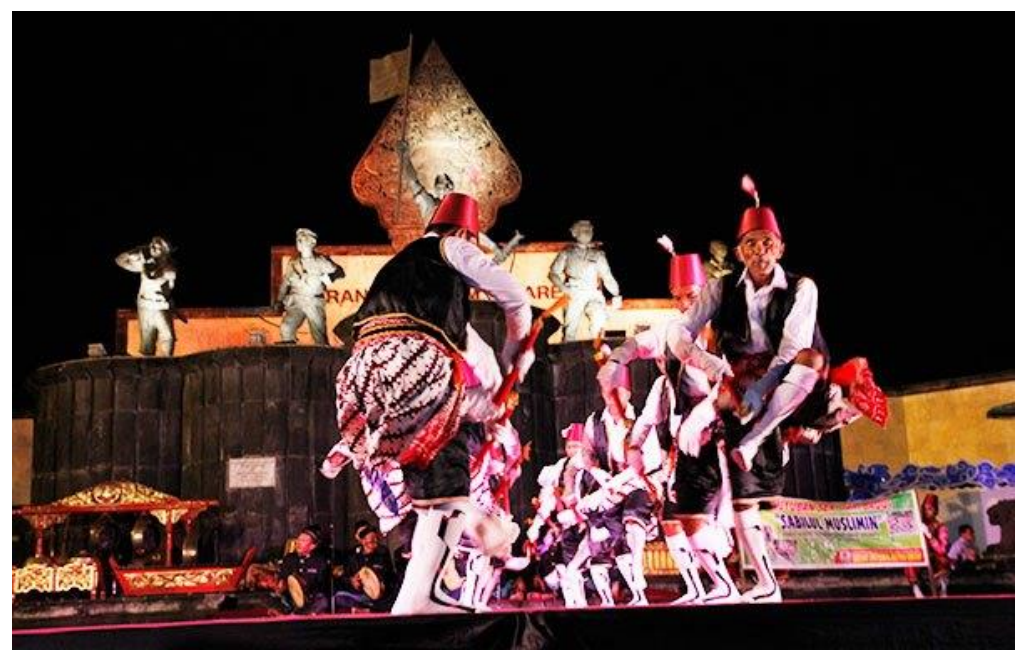

Gambar 2: Tari Badui Sleman Yogyakarta

Perbedaan estetika muncul ketika seni tari bertemu dengan pendidikan sebagai sebuah lembaga. Sesuai dengan fungsinya bahwa lembaga pendidikan tinggi memiliki tugas utama dalam meramu pengetahuan untuk disebarluaskan kepada mahasiswa melalui dosen sebagai agennya. Menurut pada pendidikan di sekolah dasar, menengah 
dan atas, seni tari memiliki tempat tersendiri sebagai salah satu bentuk ilmu pengetahuan. Terlebih lagi negara Indonesia terkenal dengan multikulturalnya, sehingga kini seni menjadi mata pelajaran wajib di sekolah-sekolah. Adapun perkembangan seni tari di perguruan tinggi non seni tidak sepenuhnya masuk pada kurikulum sebagai mata kuliah. Akan tetapi, seni tari menjadi pilihan yang bisa diikuti oleh mahasiswa dalam kelompok studi mahasiswa dan Unit Kegiatan Mahasiswa (UKM). Penerapan aturan tersebut tentu berdasar atas peran pendidikan tinggi sebagai penerjemah ilmu pengetahuan. Seni dikembangkan dan dipelajari seluas-luasnya untuk mewadahi minat dan bakat mahasiswa dalam bidang seni. Dengan demikian, maka estetika seni dapat terwujud tanpa harus berkompromi dengan norma dan aturan di luar kesopanan. Pendidikan tinggi menjalankan fungsinya sebagai media komunikasi estetika dalam seni tari dan mewadahi perkembangan seni hingga dapat disebarluaskan sebagai hasil dari ilmu pengetahuan.

Estetika yang muncul ketika pendidikan dan Islam saling beririsan. Menurut istilah estetika sendiri sebagai sebuah keindahan secara harafiah, dalam hal ini dimaknai sebagai tataran nilai yang muncul saat Islam bertemu dengan pendidikan. Sesuai dengan peran lembaga pendidikan tinggi sebagai lembaga yang melakukan transfer knowledge, maka Islam dalam hal ini menjadi salah satu sub bagian ilmu pengetahuan yang ditanamkan melalui lembaga pendidikan. Agama Islam sebagai salah satu agama terbesar di Indonesia memiliki aturan-aturan yang selanjutnya digunakan sebagai panduan hidup dalam perilaku habluminallah (manusia dengan Allah) dan habluminannas (manusia dengan manusia). Begitu pentingnya nilai Islam dalam pembentukan nilai pada anak sehingga perlu ditingkatkan dengan kegiatan ekstrakurikuler berbasis kerohanian (Rouf, 2015). Pendidikan menjadi lembaga yang menjaga nilai simbol konsistensi agama dan melakukan penyebaran pengetahuan nilai-nilai agama sebagai panduan hidup. Nilai tersebut yang menjadi dasar kurikulum pendidikan Indonesia yang memasukkan materi agama secara berkelanjutan dari tingkat sekolah dasar hingga perguruan tinggi. Hal ini selaras dengan Pancasila sila pertama yaitu Ketuhanan Yang Maha Esa.

Estetika persepsi yang muncul sebagai hasil dari pertemuan antara Islam, seni dan pendidikan. Penyebutan estetika persepsi ini dilatarbelakangi atas munculnya estetika baru karena adanya negosiasi-negosiasi nilai di dalamnya. Pertemuan antara etika dalam Islam dan estetika dalam seni tari membaur menjadi satu atas nama ilmu pengetahuan dalam pendidikan. Segala objek dalam pendidikan akan selalu dimaknai sebagai pengetahuan sehingga tidak bisa lebih menonjol satu sama lain. Seluruhnya dalam posisi yang sama dan disebarluaskan sebagai perkembangan ilmu pengetahuan. Peran pendidikan dalam seni dan agama juga dikuatkan dalam penelitian Saidah (2008) yang menyatakan bahwa berfungsi untuk memberikan penyadaran bahwa seni budaya sebagai penjelmaan olah akal, budi, cipta rasa, karsa dan karya manusia bukan hanya sekedar hal yang mubah melainkan merupakan kebutuhan. Seni tari yang bertemu dengan Islam dalam dunia pendidikan menghasilkan sebuah konsep 'tari Islami' yang mengalami berbagai negosiasi dalam sajiannya. Salah satu contoh sajian 
tari Islami di perguruan tinggi Islam adalah selalu menggunakan hijab dan manset sebelum menggunakan kostum tarian. Hal ini dimaksudkan agar aurat penari tidak terlihat. Akan tetapi, estetika kostum tari tetap dapat ditampilkan.

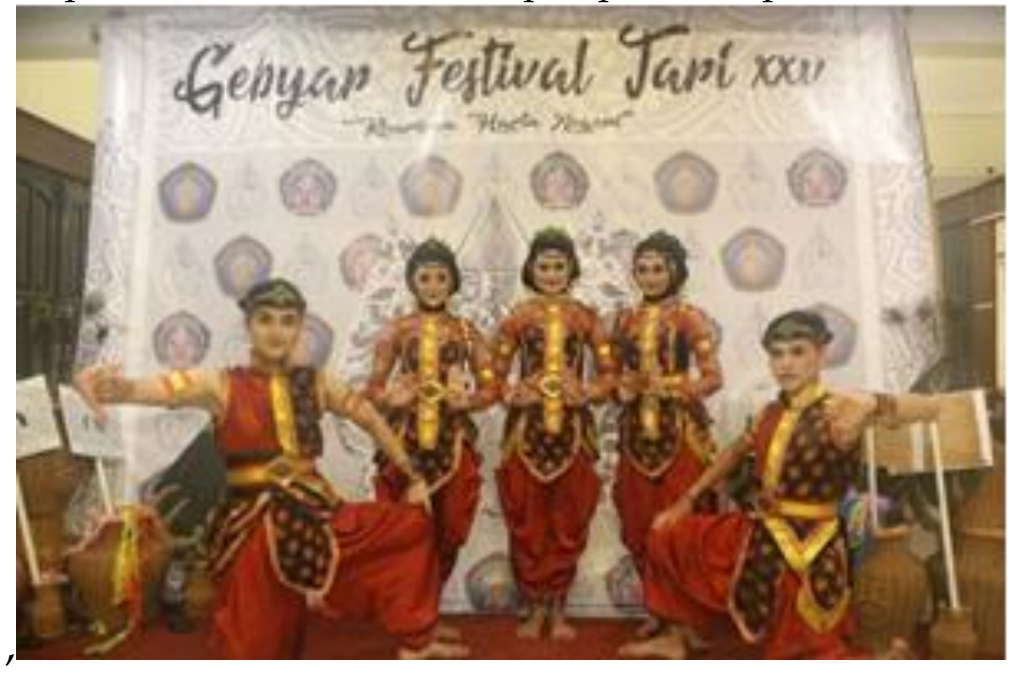

Gambar 3. Penari Laki-laki dan Perempuan dari UAD dalam Acara Festival

Pemilihan jenis tari tentunya perlu memperhatikan aspek etika dalam keIslaman. Gerak-gerak yang erotis harus diubah menjadi lebih sopan agar tidak menimbulkan syahwat bagi penontonnya. Perubahan tersebut diperbolehkan, karena pada prinsipnya tari yang dikembangkan merupakan tari kreasi. Selanjutnya, berkaitan dengan penari berpasangan (laki-laki dan perempuan), baiknya tidak perlu dibatasi dalam tari Islami di perguruan tinggi. Hal ini mengingat bahwa tarian berpasangan di Indonesia sangat banyak sehingga perlu ditampilkan untuk menambah pengetahuan. Meskipun demikian, aturan dalam bergerak juga perlu diperhatikan agar tidak melanggar etika dalam Islam. Salah satu di antaranya adalah tidak diperbolehkan saling bersentuhan secara langsung antara penari laki-laki dan perempuan.

Negosiasi-negosiasi penting dilakukan dalam menyatukan prinsip etika dalam Islam dan estetika dalam seni tari pada konteks pendidikan. Negosiasi tersebut hendaknya diterima oleh berbagai pihak tanpa harus merasa benar dan menyalahkan pihak lain yang berbeda pandangan dengan konsep tari Islami yang kita pahami. Melalui konsep estetika persepsi ini diharapkan dapat digunakan sebagai acuan pengembangan seni tari Islami di perguruan tinggi Islami Indonesia.

\section{SIMPULAN}

Estetika tari yang berkembang di perguruan tinggi Islam berbeda-beda sesuai dengan penafsiran masing masing tentang tari yang Islami. Estetika persepsi muncul dari pertemuan antara Islam, seni tari dan pendidikan. Integrasi antara ketiga unsur tersebut membentuk sebuah estetika persepsi tentang tari Islami di perguruan tinggi Islam. Tari tidak hanya berdiri di ranah estetis namun juga berkolaborasi dengan etika dalam norma agama, sementara pendidikan menjadi jembatan antara keduanya. Atas 
dasar sebagai ilmu pengetahuan, maka segala bentuk seni tari diperbolehkan selama memenuhi unsur kesopanan di perguruan tinggi Islam. Tentu hal ini perlu penyesuaian agar ranah estetis seni tari dapat tetap berjalan tanpa meninggalkan unsur etika dalam norma dalam Islam sebagai bentuk ilmu pengetahuan. Melalui konsep estetika persepsi diharapkan dapat digunakan sebagai acuan baik oleh mahasiswa maupun perguruan tinggi dalam mengembangkan tari Islami di lingkungan perguruan tinggi Islam di Indonesia.

\section{DAFTAR PUSTAKA}

Anjani, K. (2015). Apa Itu Musik.? Jakarta: Marjin Kiri.

Aprilina, F. A. D. (2014). Rekonstruksi Tari Kuntulan Sebagai Salah Satu Identitas Kesenian Kabupaten Tegal. Jurnal Seni Tari, 3(1), 1-8. Retrieved from http:// journal.unnes.ac.id/sju/index.php/jst\%0arekonstruksi

Asriati, A. (2012). Tari Pasambahan dan Falsafah Minang dalam Perspektif Alim Ulama Kota Padang. Humanus, 12(2), 145. https:/ / doi.org/10.24036/jh.v 11i2. 2164

Caturwati, E. (1998). Tari Kreasi dan Perkembangannya (Kapita Selekta Tari). Bandung: STSI Press.

Mauidhah, C. A. (2017). Pesan-pesan Komunikasi Islam dalam Tarian Tradisional Seudati Aceh (Analisis Semiotika). Jurnal Komunikasi Islam, 2(1), 29-40.

Milles, H. \&. (1992). Analisis Data Kualitatif. Terjemahan Tjetjep Rohendi Rohidi. Jakarta: Universitas Indonesia Press.

Nasution, N. A. (2017). Seni Islam sebagai Media Dakwah (Studi Kasus: Kesenian Tari Badui di Dusun Semampir, Desa Tambakrejo, Kecamatan Tempel, Kabupaten Sleman, Yoyakarta). JUSPI: Jurnal Sejarah Peradaban Islam, 1(2), 298-310.

Nurdin. (2016). Perkembangan Fungsi dan Bentuk Tari Zapin Arab di Kota Pelembang (1991-2014). Gelar, 12(2), 173-182. https://doi.org/https://doi.org /10.33153/glr.v12i2.1525

Opsantini, R. D. (2014). Nilai- Nilai Islami dalam Pertunjukan Tari Sufi pada Grup "Kesenian Sufi Multikultur" Kota Pekalongan. Jurnal Seni Tari, 3(1), 1-13.

Rizali, N. (2012). Kedudukan Seni dalam Islam. Jurnal Kajian Seni Budaya Islam, 1(1), 1 8. Retrieved from http://digilib.uin-suka.ac.id/8749/1/Nur Saida Pendidikan Agama Islam dan Pengembangan Seni Budaya Islam.pdf

Rohidi, T. R. (2016). Pendidikan Seni Isu dan Paradigma. Semarang: Cipta Prima Nusantara.

Rouf, A. (2015). Potret Pendidikan Agama Islam Di Sekolah Umum. Pendidikan Agama Islam, 3(1), 187-206.

Rusliana, I. (1999). Aspek Manusia Dalam Tari dan Aspek Manusia Dalam Seni Pertunjukan. Bandung: STSI Press.

Saeed, K. M. (2011). Islamic Art and Its Spiritual Message. International Journal of Humanities and Social Science, 1(2), 227-234.

Saidah, N. (2008). Pendidikan Agama Islam dan Pengembangan Seni Budaya Islam. 
Pendidikan Agama Islam dan Pengembangan Seni Budaya Lslam, 5(1).

Suryajaya, M. (2016). Sejarah Estetika: Era Klasik Sampai Kontemporer. Jakarta: Gang Kabel.

Sutrisno, L. B. (2011). Pengaruh Islam dalam Kesenian Setrek di Magelang, 12(1). https://doi.org/https://doi.org/10.24821/resital.v12i1.452

Wiley, J., \& Son. (2010). Multicultural Education Issues and Perspective. (J. A. B. and C. A. M. G. Bank, Ed.). United State of America: RRD Crawfordsville.

Wittgenstein, S. (2007). Aesthetics and Morality. New York: Continuum. 